\title{
Antioxidant Potential of Marolo Jam (Annona crassiflora Mart) during Storage
}

\author{
Clarissa Damiani1, Edson Pablo Silva1 ${ }^{*}$, Fernanda Salamoni Becker1, Douglas Enrico Endrigo², \\ Eduardo Ramirez Asquieri', Flávio Alves da Silva1, Eduardo Valério de Barros Vilas Boas ${ }^{3}$
}

${ }^{1}$ Escola de Agronomia, Departamento de Ciência dos Alimentos, Universidade Federal de Goiás, Avenida Esperança, s/n. Campus Samambaia, Goiania, Brazil

${ }^{2}$ Instituto de Fosfato Biológico, Goiania, Brazil

${ }^{3}$ Universidade Federal de Lavras pelo Departamento de Ciência dos Alimentos, Lavras, Brazil

Email: *edsonpablos@hotmail.com

How to cite this paper: Damiani, C., Silva, E.P., Becker, F.S., Endrigo, D.E., Asquieri, E.R., da Silva, F.A. and de Barros Vilas Boas, E.V. (2017) Antioxidant Potential of Marolo Jam (Annona crassiflora Mart) during Storage. Open Access Library Journal, 4: e3158.

https://doi.org/10.4236/oalib.1103158

Received: March 19, 2017

Accepted: May 5, 2017

Published: May 8, 2017

Copyright $\odot 2017$ by authors and Open Access Library Inc.

This work is licensed under the Creative Commons Attribution International License (CC BY 4.0).

http://creativecommons.org/licenses/by/4.0/

c) (i) Open Access

\begin{abstract}
Marolo is a typical fruit of Brazilian Cerrado Biome or Savannah Brazilian, consumed for many years by the regional population, and little known in other regions. This research aimed to study physical and chemical characteristics of jam and evaluate the presence and behavior of antioxidants to over 12 months of storage. Values were determined for humidity, ash, protein, lipids, carbohydrates, calories, sugar, fiber, pectin, $\mathrm{pH}$, total acidity, organic acid form, antioxidant potential (dpph), total phenolic compounds, color and consistency. Results of sugars, fiber and pectin showed that the consistency of Marolo fruit was suitable for the production of jam and it was within the norms established by the Brazilian legislation. The $\mathrm{pH}(3.31$ - 3.2), total phenolic compounds (394.41 - $250.5 \mathrm{mgEAG} .100 \mathrm{~g}^{-1}$ ), total antioxidant potential $(38.0 \%-33.7 \%)$, the color parameters $\left(L^{*} b * 14.45-6.6332 .19-28.52\right)$ and organic acids decreased. However, for a total acidity of variables $(1.27 \%$ to $1.53 \%)$ and citric acid ( 1.86 to $4.38 \mu \mathrm{g} \cdot \mathrm{g}^{-1}$ ) being detected increment in values. With these results, we may say that Maroloto jam over a year of storage remained with good amounts of nutrients and a good antioxidant capacity.
\end{abstract}

\section{Subject Areas \\ Food Science, Technology}

\section{Keywords}

Free Radicals, Savannah Brazilian, Tropical Fruits

\section{Introduction}

Horticulture at Brazilian Cerrado biome is a promising economic activity, given 
the diversity and potential of Annona species, which fruits may be used as a nutritious food, but mainly as a raw material for industrial process. Among natives cerrado's fruits of the state of Minas Gerais, marolo, is an understudied and use on food technology. The "maroleiro" (Annona crassiflora Mart.) is a fruitful tree of Brazilian cerrado's biome, known as Araticum or "cabeçapreta". The fruit is berry type, green when it is growing and brown when ripe [1].

Pulp is slightly sweet and pleasant aroma, showing variation in color which goes from white to yellow. The yellow fruit pulp is more accepted in the consumer market, presenting more pronounced flavor and aroma. Diversity of fruits at Brazil may boost the agribusiness sector, increasing the demand for regional products in large urban centers, considering the population expectance and the market as well [2].

To expand the market of national and international fresh fruits, Brazil needs to urge the consumption of fruits and it by-products, raising the interest of consumers for developed products in the way of juice, pulp, candies, jams, and other types. However, a factor of concern to consumers is the benefit which products may provide health, making these interesting fruits due the significant contribution of bioactive compounds, such as antioxidants. Antioxidants are chemical substances which react with free radicals and thus limit the adverse effects thereof on the body. The body has the ability to produce certain endogenous antioxidants, though most come from food intake [3]. Natural antioxidants have been largely used in some industries and medicine. Frequently, therapeutics benefits of fruits, vegetables and herbs are associated with antioxidant capacity. Prophylactic use of wines and teas is associated to substances such as phytoantioxidants which are recommended by nutritionists for the cancer prevention, cardiovascular disease and other serious chronic diseases. Among the numerous examples of total phenolic compounds abundant in plants and with antioxidant properties, it may be cited flavonoids, tannins, catechol, caffeic acid, chlorogenic acid, and ascorbic acid [4].

Therefore, this research aimed to use the marolo fruit as raw material on jam production, adding value to this typical fruit of the Brazilian cerrado biome, being evaluated the nutritional characteristics, technological, antioxidants compounds, and the product coloration during 12 months of storage.

\section{Material and Methods}

Fruits from state of Minas Gerais, Brazil, were used, harvest 2011/2012, from March to April were selected through their appearance such as absence of injuries and decay. After then, they were taken to the Postharvest Laboratory of Fruits and Vegetables of the Federal University of Lavras, Brazil, where they were selected, Aiming uniformity with respect to degree of ripeness and texture. Then, they were washed in water to remove surface contaminations and sanitized by using a solution of sodium hypochlorite $300 \mu \mathrm{L} \cdot \mathrm{L}^{-1}$ for 20 minutes. After the sanitization process, the fruits were peeled and it pulp bottled and frozen for further processing to obtain the jam. 
Jams such as "extra", incremented with $50 \%$ of fruits and 50\% sugar [5], were developed using the method according to the manual of jam fabrication by Lopes [6]. Were used $6.0 \mathrm{~kg}$ of fruit pulp, $30.0 \mathrm{~g}$ of commercial pectin with high content of methoxylation, $60 \mathrm{~g}$ of citric acid (amount necessary to reach the $\mathrm{pH}$ 3.2 of the pulp) and $6.2 \mathrm{~kg}$ sugar to batch fabrication.

To pack the jam at $85^{\circ} \mathrm{C}$, it was used glass bottles of $150 \mathrm{~g}$ previously sterilized. The glass bottles were disposed in an exhaust tunnel (Incasl Máquinas, Brazil) to form an empty space inside. Lids also went through the same sterilization process, during 5 minutes, cooled and packed in cardboard boxes, then stored protected from light for a year at room temperature $\left(\approx 25^{\circ} \mathrm{C}\right)$. After the jam production, were performed in triplicate the following analyzes: proximal composition, antioxidants compounds (dpph), total phenolic compounds, $\mathrm{pH}$, total titratable acidity, organic acids and color $\left(\mathrm{L}^{\star}, \mathrm{a}^{\star}, \mathrm{b}^{\star}\right)$.

These same analyses were repeated every two months during a year of storage. Humidity, ashes, proteins, lipids, $\mathrm{pH}$, total titratable acidity, soluble solids, reducing sugars and sucrose analyses were performed according to AOAC [7]; total carbohydrates were determined by sulfuric phenol method described by Dubois et al. [8] and results expressed as percentage. Calculation of it total caloric value, was performed using Atwater conversion and results were expressed in Kcal; for total and soluble pectin content determination, was used colorimetric method by [9]; consistence was determined with the aid of texturometer TATX2 (Texture Technologies Cor, EE. UU.) and results were expressed in Newton; organic acids were extracted according to Bazimarakenga et al. [10], with modifications, identified and quantified by HPLC of Gilson Inc. brand (Middleton, WI), with a pump 306, and automatic gas injector ASTED XL and software 712 with detector UV/VIS Gilson 118 using a C-18 reverse phase column $(150 \times 4.6$ $\mathrm{mm}$ ). Injected sample volume was approximately $20 \mathrm{uL}$, using water as the mobile phase, with $0.1 \%$ of phosphoric acid, with a flow $1 \mathrm{ml} \cdot \mathrm{min}^{-1}$. Peaks corresponding to each identified acid through retention time and comparing the standard retention times and chemical structure of each specific acid, results were expressed in $\mu \mathrm{g} \cdot \mathrm{g}^{-1}$; antioxidant potential was determined by the DPPH method according to Borquini \& Torres (2009). The degree of discoloration of DPPH at $517 \mathrm{~nm}$ by the action of antioxidants, was measured by spectrophotometry (700 Plus, Fento, Brasil) on ethereal extracts, ethanol and aqueous at concentrations of $0.2 \mathrm{mg} \cdot \mathrm{mL}^{-1}$. Results were expressed as percentage of DDPH discoloration; extraction of phenolic compounds (ethanol, aqueous and total), were performed according to Genovese et al. (2003), with Folin-Ciocalteu. Determination of phenols followed the methodology of Zieliski e Kozowska [11] [12] and results expressed in mgEAG $100 \mathrm{~g}^{-1}$; color were determined with aid of Minolta colorimeter CR-400 (Minolta, Japan) on CIE $\mathrm{L}^{*}, \mathrm{a}^{*}$ and $\mathrm{b}^{*}$ model. Coordinate $\mathrm{L}^{*}$ means how much lighter or darker is the jam, with values among 0 (totally dark) and 100 (totally white); coordinated $\mathrm{a}^{*}$ might take values among -80 to +100 , where extremes correspond to green and red respectively, coordinate $b^{*}$ might vary from -50 to +70 , with intensity from blue to yellow; Readings were per- 
formed at three different points of jam.

Experiment was conducted in a completely randomized design, simple, factor $3 \times 7$, made with 3 repetitions and 7 levels of the time factor $(0,2,4,6,8,10$ and 12 months) being performed analyzes of antioxidant compounds, phenolics, $\mathrm{pH}$, titratable acidity, organic acids, color $\left(\mathrm{L}^{*}, \mathrm{a}^{*}, \mathrm{~b}^{*}\right)$. Each experimental parcel was constituted of a package which contained 150 grams of jam.

Microbiological analyzes for fungi and yeasts, Salmonella $s p$, thermotolerant and total coliforms were performed according to the methodology proposed by ICMSF [13].

The statistical processing of data was performed using the software SISVAR [14].

After the analysis of variance, polynomial regression models were selected based on the significance of proof $F$ of each studied model and determined by its coefficient.

\section{Results and Discussion}

\subsection{Chemical and Physical Composition}

Results for chemical and physical composition of marolo jam after fabrication (zero time), are represented in Table 1.

Humidity content detected in samples are within the norms established by Brazilian legislation, which indicates a maximum of $35 \%$ weight/weight, for extra jam type [5]. Ash content obtained an average of $0.24 \%$.

Protein content detected in developed jam formulation was smaller than amount found in fresh fruits (1.99\%), which may have occurred due sugar addition in the new product formulation. Total content of carbohydrates is due the large part of incremented sugar quantity in jam's fabrication (6.2 kg of sugar and $6.0 \mathrm{~kg}$ of fruit pulp), which influenced directly on caloric values.

For lipids content, before the transformation process of pulp to jam, was detected values of $2.36 \%$, right after the process, was verified a significant decrement of it nutrient around $72.45 \%$. Decrement detected on lipid content may

Table 1. Chemical and physical composition (humid base) of marolo jam storage at room temperature protected from light. Goiânia, Goiás.

\begin{tabular}{cccc}
\hline Component & Average Values & Component & Average values \\
\hline Humidity (\%) & $32.34 \pm 2.5$ & Sucrose (\%) & $27.77 \pm 2.5$ \\
Ashes (\%) & $0.24 \pm 0.3$ & Soluble solids ( $\left.{ }^{\circ} \mathrm{Bx}\right)$ & $65.23 \pm 1.5$ \\
Proteins (\%) & $0.83 \pm 0.15$ & Dietary fiber (\%) & $0.61 \pm 0.1$ \\
Lipids (\%) & $0.65 \pm 0.21$ & Total pectin (\%) & $1.23 \pm 0.1$ \\
Total carbohydrates (\%) & $63.71 \pm 0.89$ & Soluble pectin (\%) & $0.52 \pm 0.2$ \\
Energetic value (Kcal) & $272.01 \pm 2.7$ & Insoluble pectin (\%) & $0.71 \pm 0.1$ \\
Total soluble sugars (\%) & $60.59 \pm 2.1$ & Texture (N) & $0.45 \pm 0.2$ \\
Reducing Sugars (\%) & $33.26 \pm 2.2$ & & \\
\hline
\end{tabular}

*Average values and standard deviation. 
have been enabled probably due lipid oxidation process during process, which occurs when there is the action of temperature on lipids, converting them in acids, ketone, aldehydes, among others, mainly when there is sugar addition in jam fabrication [15].

Levels of reducing sugars were superior to sucrose level. This may be explained by cooking process for jam obtainment, where sucrose in an acid solution undergoes an inversion process, turning into glucose and fructose (invert sugar). Inversion process of sucrose is required to avoid crystallization which may be produced in certain stages of process [6].

Soluble solids of marolo jam, whose main component is represented by total soluble sugars and also organic acids, are in accordance with Brazilian legislation [5], which stipulates a minimum of $65^{\circ} \mathrm{Bx}$.

There was a reduction of $86.32 \%$ on fiber content comparing with fresh fruit (4.46\%) [16], this reduction may be due jam processing, Once to obtain the juice, filtering processes have been performed (pulping) which may have led to the loss of good amount of fiber present [16].

The smallest amount of soluble pectin found in comparison with the insoluble pectin may be associated with a greater degree of methylation $(\mathrm{CH} 3)$, using in marolojam. Consistency (texture) of jam was $0.45 \mathrm{~N}$ and is linked to concentration of pectin and sugar/acid content present in the sample.

Behavior of $\mathrm{pH}$, total acidity and organic acids observed during one year of storage, is shown in Figure 1.

Analyses of $\mathrm{pH}$, total acidity, and organics acids, were influenced over time ( $p$ $\leq 0.01$ ). Was detected a slight decrement of $\mathrm{pH}$, while the acidity increased, probably due accumulation of acetic acid during the storage. Reduction of acetic acid content between 0 and $4^{\text {th }}$ month storage, may be due a probable action of antimicrobial compounds which exist in species of Annonaceae family [17]. However, this antimicrobial compounds may have been depleted during storage time, which could conduct to acetic acid production by fungi which ferment sugar, making the residual alcohol, in the presence of oxygen and added to the gel and thus converted into acetic acid [18]. Marolo is not a fruit rich in vitamin C $\left(9.5 \mathrm{mg} \cdot \mathrm{g}^{-1}\right)$, this nutrient has been significantly reduced around $97 \%$, during processing, probably due an accelerated oxidation caused by high temperatures in gelation.

Ascorbic acid was detected only until the second month of storage, which become imperceptible at the end of experiment. Loss of vitamin C is initially produced by chemical degradation which involves the ascorbic acid oxidation on dehydroascorbic acid, and it is known that the heating increases the speed of the oxidation process [19]. Another possible explanation is the degradation of ascorbic acid due low humidity and also by the consumption in Maillard reaction [15] [20].

Malic acid (89.2\%), tartaric acid (96.55\%) and citric acid (27\%), decreased during storage. Organic acids found in marolo fresh fruits are: $294 \mathrm{mg} \cdot \mathrm{g}^{-1}$ of citric acid, $958.5 \mathrm{mg} \cdot \mathrm{g}^{-1}$ of malic acid, and absence of tartaric acid and acetic acid 

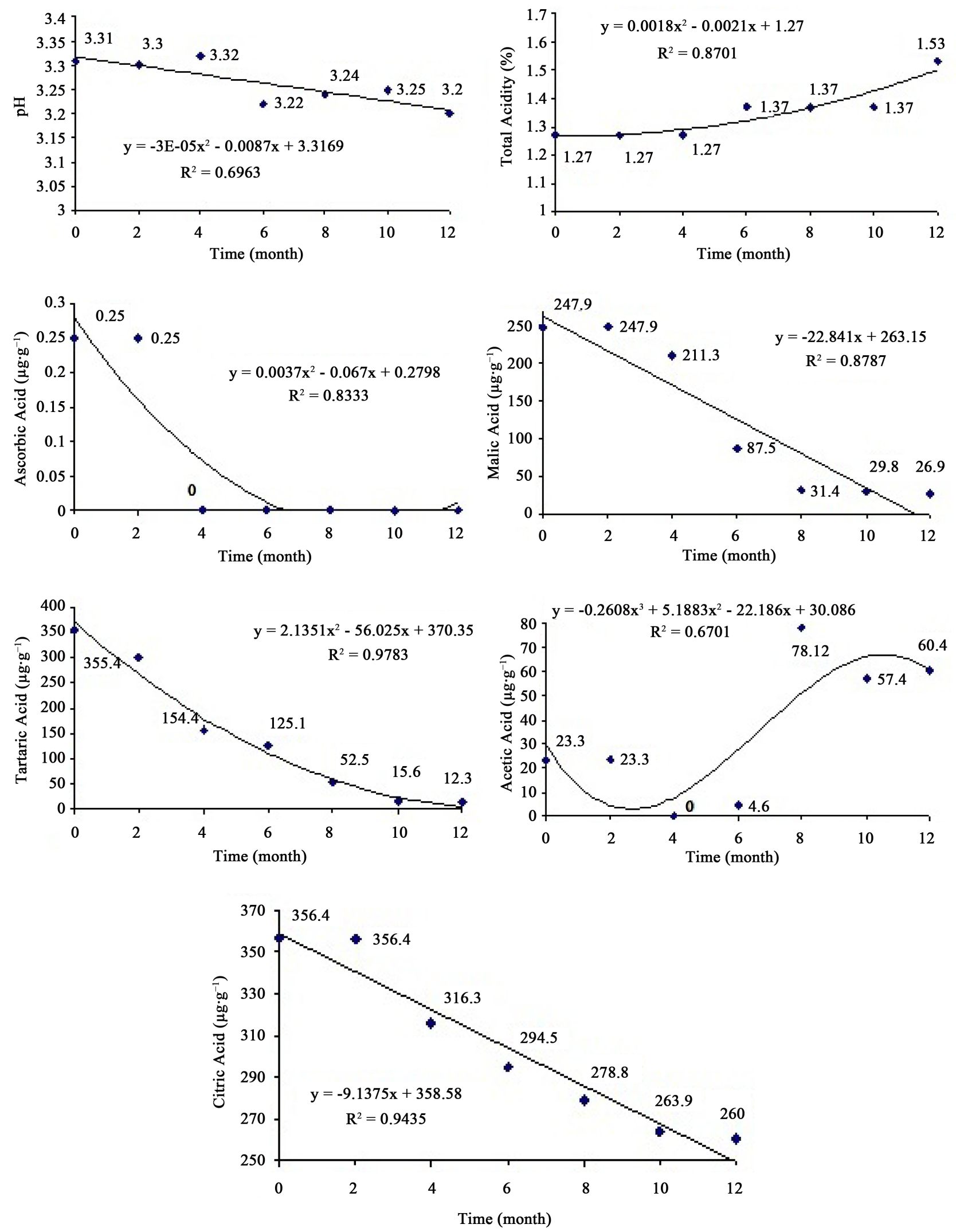

Figure 1. Average values of $\mathrm{pH}$, total titulable acidity (\%), ascorbic acid $\left(\mu \mathrm{g} \cdot \mathrm{g}^{-1}\right)$, malic acid $\left(\mu \mathrm{g} \cdot \mathrm{g}^{-1}\right)$, tartaric acid $\left(\mu \mathrm{g} \cdot \mathrm{g}^{-1}\right)$, acetic acid $\left(\mu \mathrm{g} \cdot \mathrm{g}^{-1}\right)$ and citric acid $\left(\mu \mathrm{g} \cdot \mathrm{g}^{-1}\right)$ in marolo jams, storage at room temperature $\left(25^{\circ} \mathrm{C}\right)$ protected from light, during twelve months. Goiânia, Goiás. 
[16]. Detected reduction of malic, tartaric and citric acids in jams may be associated to evaporation during process and also by consumption by fungi and yeasts presents in the product. Fungi action present in sample may decarboxylate malate to pyruvate, which is then carboxylated for acetaldehyde, finally being reduced to ethanol. Increase in citric acid content relative to fresh fruit may be due incorporation of ingredients in jam formulation.

Fungi and yeasts are most common microorganisms which are found in products with high sugar concentration and low $\mathrm{pH}$. However, results obtained on this experiment, were within the limits set by the National Agency for Sanitary Surveillance-ANVISA [21], which provides for fruit jam maximum of 104 $\mathrm{UFC} \cdot \mathrm{g}^{-1}$ for fungi and yeasts.

At time zero, was not detected presence of these microorganisms. From second to sixth month storage was observed presence of microorganisms, with values of $4 \times 10^{2} \mathrm{UFC} \cdot \mathrm{g}^{-1}$, reducing to $1 \times 10^{1} \mathrm{UFC} \cdot \mathrm{g}^{-1}$ until the end of storage. There was not observed presence of Salmonella sp, as well coliforms at $35^{\circ} \mathrm{C}$ and $45^{\circ} \mathrm{C}$. Results showed that technological procedures adopted were well prepared as well the manipulation and proper sanitization of fruits, especially the equipment used.

\subsection{Total Antioxidant Potential}

Marolo jam contains nutrients such as proteins, carbohydrates, lipids, sugars which provide good calories, contain antioxidants, beneficial substances for health. These total phenolic compounds were influenced over time $(p>0.01)$ and results are shown in Figure 2.

Was observed an increase of total antioxidant potential and of antioxidants substances presents in extract with ethanol and aqueous extract until eighth month storage and right then occur a reduction until twelfth month. Was noticed that for oxidants found in ether extract, showed no increase, while those found in extracts with ethanol and total, decrease comparing to the initial value and only those substances founding in aqueous extract, obtained increment during one year storage. Presence of different antioxidant compounds in plants tissues such fruits and vegetables, makes it relatively difficult to measure the antioxidant activity of each component separately. Several solvents certified maximum solubility of antioxidants in the sample. Use of three solvents in different proprieties, ethyl ether (2.9), ethanol (5.2) and distilled water (9), allowed the solubility of polar compounds (aqueous extract), intermediate polarity (ethanol extract) and polar (ether extract).

Typical compounds which has antioxidant activity includes the class of phenols, phenolic acids and it derivatives, flavonoids, tocopherols, phospholipids, ascorbic acid, pigments and steroids [22]. Zafrilla \& Tons-Barber [23], studied the effects of antioxidants as the ellagic acid during storage of raspberry jam (Rubusidaeus) and was confirmed that during 6 months of storage occurred an increase of antioxidant activity, similar behavior to what occurred with marolo jams, detected in ethanol and aqueous extracts, probably due the presence and action of ellagic acid. 

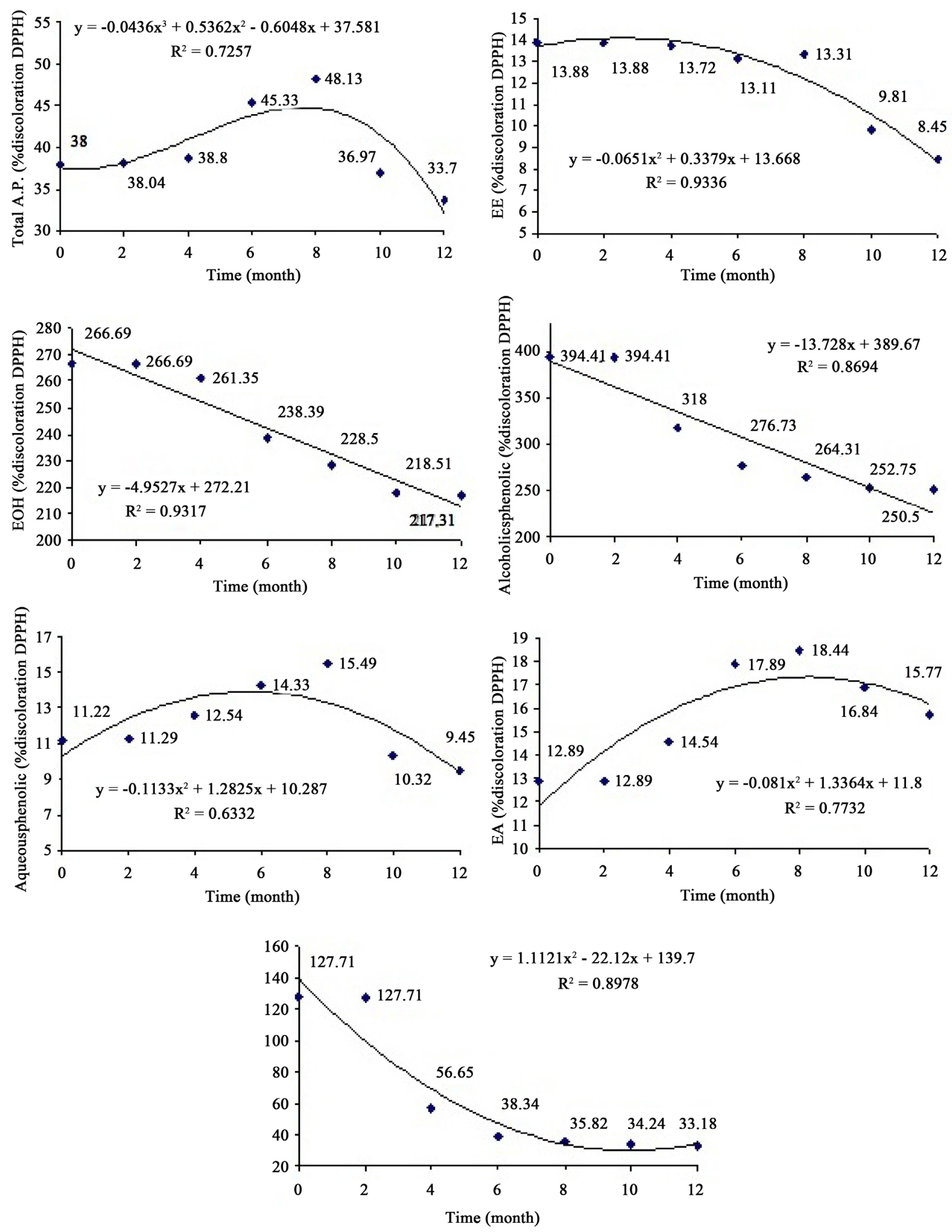

Figure 2. Total antioxidant potential (PA), ether extract (EE), ethanol extract (EOH), aqueous extract (EA), all examples expressed in \% of DPPH radical discoloration and totalphenolic compounds in aqueous extract, ethanol extract and total (mg EAG ${ }^{*}$ $\left.100 \mathrm{~g}^{-1}\right)$ in marolo jam, stored at room temperature $\left(25^{\circ} \mathrm{C}\right)$ protected from light, during 12 months. ${ }^{\star}$ EAG: equivalents of gallic acid; Norm BHT $0.05 \mathrm{mg} \cdot \mathrm{mL}^{-1}=96.27 \% ; 0.1 \mathrm{mg} \cdot \mathrm{mL}^{-1}=100 \%$. Goiânia, Goiás. 
Increase of antioxidant capacity also may originate from Maillard reaction products, such as amino-reducing agent, which also has an antioxidant effect.

However, reduction after 12 months storage, may be possibly explained by degradation of anthocyanins as a function of temperature above $20^{\circ} \mathrm{C}$ (storage was done at $25^{\circ} \mathrm{C}$ ), also observed by Wicklund et al. [24], when evaluated the antioxidant activity and coloration of strawberry jams during storage.

About phenolic compounds, were found in ethanol and aqueous extracts, reducing it content with the storage period. This decrease is explained by instability of compounds at temperature of $23^{\circ} \mathrm{C}$ and then of $40^{\circ} \mathrm{C}$ (temperature conditions wherein marolo jams were), according to studies performed by [25], when evaluated the effect of storage temperature on the stability of phenolic compounds in fruit.

Kim and Padilla-Zakou [26], studied the processing effect on phenolic compounds in cherry jam and observed a decrement in the post-processing compound with values of $199.9 \mathrm{mg}$ EAG $100 \mathrm{~g}^{-1}$ and $218.9 \mathrm{mg}$ EAG $100 \mathrm{~g}^{-1}$ respectively. Lower values were found for marolo jam at the beginning of storage (394.41 mg EAG $100 \mathrm{~g}^{-1}$ ). Yuyama et al. [27], researching about cocona jam (Solanumsessiliflorum Dunal), detected a reduction of phenolic compounds during storage (180 days), finding values of $277.86 \mathrm{mg}$ EAG $100 \mathrm{~g}^{-1}$ and $235.69 \mathrm{mg}$ EAG $100 \mathrm{~g}^{-1}$.

Color parameters (value $\mathrm{L}^{*}$ and $\mathrm{b}^{*}$ ) also were influenced by time factor $(p>$ $0.01)$, being detected a reduction for these coordinates. However, for coordinate $\mathrm{a}^{*}$ was not observed modification during 12 months storage. Reduction of $\mathrm{L}^{*}$ value indicated a darkening of product, probably due appearance of Maillard reaction and/or hydroxymethylfurfural formation (HMF), with oxidation of vitamin C. This dark substance was detected during fruit jam storage at $25^{\circ} \mathrm{C}$, studied by Rada-Mendoza et al. [28]. In products with high concentration of reducing sugars, these join to free amino acids or those forming part of protein chains, forming dark compounds. At a $\mathrm{pH}$ lower than 5, arises an intermediate product which undergoes dehydration, originating HMF. This happens during heating, so, in jam production, as well as during prolonged storage period. In addition the sugars, carbonic fraction may be caused by oxidation of lipids, also contributing the Maillard reaction [14]. Cardoso [29], studying the stability of the jams color stored at $25^{\circ} \mathrm{C}$ and $35^{\circ} \mathrm{C}$ during 180 days, verified a reduction of $\mathrm{L}^{*}$ value, with an increment of darkening during storage, and a consequent decrease in $b^{*}$ value.

\section{Conclusions}

Marolo jam may be stored for 12 months at room temperature (approximately $35^{\circ} \mathrm{C}$ ) protected from the light, having the physics, chemicals and microbiological characteristics changed, however within the standards established by legislation.

The humidity, sucrose, total pectin, soluble pectin, $\mathrm{pH}$, antioxidant potential, total phenolic compounds, color parameters and malic, tartaric, citric and ascorbic 
acids reduced its contents during storage, however, proteins, carbohydrates, calories, total soluble sugar, reducing sugar, soluble solids, fibers, acidity, and acetic acid showed ascension during storage.

Despite these reported changes, sensorial characteristics of the new product were not affected, reaching note eight in all attributes evaluated by consumers of Goiânia, such as appearance, color, flavor and aroma, in 0, 6 and 12 months of storage.

\section{References}

[1] Lorenzi, H. (1998) Árvores brasileiras: manual de identificação e cultivo de plantas arbóreas nativas do Brasil. 2nd Edition, Plantarium, Nova Odessa/SP, $384 \mathrm{p}$.

[2] Silva, E.P., Xisto, A.L.P.R., Fante, C.A. and Vilas Boas, E.V.B. (2014) Characterization and Development of Marolo Fruit (Annona crassiflora, Mart) Ciência e Tecnologia de Alimentos (Impresso), 33, 1-10.

[3] Borguini, R.G. and Torres, E.F.S. (2009) Tomatoes and Tomato Products as Dietary Sources of Antioxidants. Food Reviews International, 25, 313-325.

https://doi.org/10.1080/87559120903155859

[4] Blasco, A.J., Gonzales, M.C. and Escarpa, A. (2004) Electrochemical Approach for Discriminating and Measuring Predominant Flavonoids and Phenolic Acids Using Differential Pulse Voltammetry: Towards an Electrochemical Index of Natural Antioxidants. Analytica Chimica Acta, 511, 71-81. https://doi.org/10.1016/j.aca.2004.01.038

[5] Brasil. (1978) Ministério da Saúde. Agência Nacional de Vigilância Sanitária. Resolução Normativa n.o 9, de 11 dez. 1978. Diário Oficial da República Federativa do Brasil, Poder Executivo, Brasília, DF. http://www.anvisa.gov.br/legis/resol/09_78_doces.htm

[6] Associations of Official Agricultural Chemists-AOAC (2005) Official Methods of the Association of the Agricultural Chemists. 18th Edition, AOAC, Maryland.

[7] Dubois, M.K.A., Gilles, H.J.K., Rebers, P.A. and Smith, F. (1956) Colorimetric Method for Determination of Sugars and Related Substances. Analytical Chemistry, 28, 350-355. https://doi.org/10.1021/ac60111a017

[8] Bitter, V. and Muir, H.M. (1962) A Modified Uronic Acid Carbazole Reaction. Analytical Biochemistry, 4, 330-334. https://doi.org/10.1016/0003-2697(62)90095-7

[9] Bazimarakenga, B., Simard, R.R. and Leurox, G.D. (1995) Determination of Organic Acids in Oil Extracts by Ion Chromatography. Soil Biology and Biochemistry, 27, 349-356. https://doi.org/10.1016/0038-0717(94)00178-4

[10] Genovese, M.I., Santos, R.J., Hassimoto, N.M.A. and Lajolo, F.M. (2003) Determinação do conteúdo de fenólicos totais em frutas. Revista Brasileira de Ciências Farmacêuticas, 39, 167-169.

[11] Zieliski, H. and Kozowska, H. (2000) Antoixidant Activity and Total Phenolics in Selected Cereal Graims and Their Different Morphological Fractions. Journal of Agricultural and Food Chemistry, 48, 2008-2016. https://doi.org/10.1021/jf990619o

[12] International Commission on Microbiological Specifications for Foods (1983) Microrganisms in Food. 2nd Edition, University of Toronto, Toronto/Canadá, 436 p.

[13] Ferreira, D.F. (2003) Programa de análises estatísticas (statistical analysis sotware) e planejamento de experimentos-SISVAR 5.0 (Build 67). DEX/UFLA, Lavras. 
[14] Fennema, O.R. (2000) Química de los alimentos. 2nd Edition, Acribia, Sarago$\mathrm{za} /$ Espanã, $1258 \mathrm{p}$.

[15] Lopes, R.L.T. (1985) Manual para fabricação de geleias. CETEC. Belo Horizonte/MG, $42 \mathrm{p}$.

[16] Damiani, C., Vilas Boas, E.V.B., Asquieri, E.R., Lage, M.E., Oliveira, R.A., Silva, F.A., Pinto, D.M., Rodrigues, L.J., Silva, E.P. and Paula, N.R.F. (2011) Characterization of Fruits from the Savanna: Araça (Psidiumguinnensis Sw.) and Marolo (Annonacrassiflora Mart.). Revista Española de Ciencia y Tecnología de Alimentos, 31, 723-729. https://doi.org/10.1590/S0101-20612011000300026

[17] Di Stasi, L.C. and Hiruma-Lima, C.A. (2002) Plantas medicinais na Amazônia e Mata Atlântica. 2nd Edition, UNESP, São Paulo/SP, 604.

[18] Snowdon, J.A. and Oliver, D.O. (1996) Microorganism in Honey. International Journal of Food Microbiology, 31, 1-23. https://doi.org/10.1016/0168-1605(96)00970-1

[19] Dewanto, V., Wu, X., Adom, K.K. and Liu, H.R. (2002) Thermal Processing Enhances the Nutritional Value of Tomatoes by Increasing Total Antioxidant Activity. Journal of Agricultural and Food Chemistry, 50, 3010-3014. https://doi.org/10.1021/jf0115589

[20] Giannakourou, M.C. and Taoukis, P.S. (2003) Kinetic Modeling of Vitamin C loss in Frozen Green Vegetables under Variable Storage Conditions. Food Chemistry, 83, 33-41. https://doi.org/10.1016/S0308-8146(03)00033-5

[21] Brasil (2001) Ministério da Saúde. Agência Nacional de Vigilância Sanitária. Resolução RDC ANVISA/MS no. 12, de 02 de janeiro de 2001. Diário Oficial da República Federativa do Brasil, Poder Executivo, Brasília, DF.

http://www.anvisa.gov

[22] Roesler, R., Malta, L.G., Carrasco, L.C., Holanda, R.B., Sousa, C.A.S. and Pastore, G.M. (2007) Atividade antioxidante de frutos do cerrado. Revista Española de Ciencia y Tecnología de Alimentos, 27, 1004-1019.

[23] Zafrilla, P., Ferreres, F. and Toms-Barbern, A. (2001) Effect of Processing and Storage on the Antioxidant Ellagic Acid Derivatives and Flavonoids of Red Raspberry (Rubusidaeus) Jam. Journal of Agricultural and Food Chemistry, 49, 3651-3655. https://doi.org/10.1021/jf010192x

[24] Wicklund, T., Rosenfeld, H.J., Martinsen, B.K., Stundfor, M.W., Lea, P., Bruum, T., Blomhoff, R. and Haffner, K. (2005) Antioxidant Capacity and Colour of Strawberry Jam as Influenced by Cultivar and Storage Conditions. Food Science and Technology, 38, 387-391. https://doi.org/10.1016/j.lwt.2004.06.017

[25] Chang, Q., Zuo, Z., Chow, M.S.S. and Ho, W.K.K. (2006) Effect of Storage Temperature on Phenolics Stability in Hawthorn (Crotaeguspinnatifida var. Major) Fruits and a Hawthorn Drink. Food Chemistry, 98, 426-430. https://doi.org/10.1016/j.foodchem.2005.06.015

[26] Kim, D.O. and Padilla-Zakour, O.I. (2004) Jam Processing Effect on Phenolics and Antioxidant Capacity in Anthocyanin-Rich Fruits: Cherry, Plum, and Raspberry, Sensory and Nutritive Qualities of Food. Journal of Food Science, 69, 395-400. https://doi.org/10.1111/j.1365-2621.2004.tb09956.x

[27] Yuyama, L.K.O., Pantoja, L., Maeda, R.N., Aguiar, J.P.L. and Silva, S.B. (2008) Desenvolvimento e aceitabilidade de geléia dietética de cubiu (Solanum sessiliflorum Dunal). Revista Española de Ciencia y Tecnología de Alimentos, 28, 929-934. https://doi.org/10.1590/S0101-20612008000400026

[28] Rada-Mendoza, M., Sanz, M.L., Olano, A. and Villamiel, M. (2004) Formation of 
Hydroxymethylfurfural and Furosine during the Storage of Jams and Fruit Based Infant Foods. Food Chemistry, 88, 605-609.

https://doi.org/10.1016/j.foodchem.2003.07.002

[29] Cardoso, R.L. (2008) Estabilidade da cor de geléia de jambo (Eugenia malaccensis L.) sem casca armazenada aos $25^{\circ} \mathrm{C}$ e $35^{\circ} \mathrm{C}$ na presença e ausência de luz. Ciência e Agrotecnologia, 32, 1563-1567. https://doi.org/10.1590/S1413-70542008000500031

Submit or recommend next manuscript to OALib Journal and we will provide best service for you:

- Publication frequency: Monthly

- 9 subject areas of science, technology and medicine

- Fair and rigorous peer-review system

- Fast publication process

- Article promotion in various social networking sites (LinkedIn, Facebook, Twitter, etc.)

- Maximum dissemination of your research work

Submit Your Paper Online: Click Here to Submit

Or Contact service@oalib.com 